\title{
A study on heavy metals accumulation and its uptake by Cowpea [Vigna unguiculata (L.) Walp.] fertilized with Sugar mill effluent and DAP treatment in two cropping seasons
}

\author{
Sachin Srivastava* and A.K. Chopra \\ Department of Zoology and Environmental Science, Gurukula Kangri University, Haridwar-249404 (UK), INDIA \\ *Corresponding author. E-mail: sachin.env@gmail.com
}

Received: April 15, 2014; Revised received: May 18, 2014; Accepted: June 5, 2014

\begin{abstract}
A study was performed under natural environment to compare heavy metal accumulation in soil and Vigna unguiculata L. (Cowpea) irrigated with five rates of SME viz. 10, 25, 50, 75 and 100\% concentrations and DAP treatment (applied @100Kg/ha i.e. $0.7 \mathrm{~g} /$ per $5 \mathrm{Kg}$ ) and control (Bore well water) separately in both the rainy (Kharif) and summer (Zaid) seasons for 90 days. Results revealed that among various concentration of SME and DAP treatment, irrigation with $100 \%$ SME concentration significantly $(\mathrm{P}<0.001)$ increased $\mathrm{Zn}(323.07-341.02 \%)$, Cu (371.23-389.04\%), Ni (3666.66-4133.33\%), Cd (525.00-725.00\%), Cr (1444.4-1477.77\%) and Fe (224.08-244.89\%) in the soil. In case of $V$. unguiculata irrigated with different SME concentrations, maximum range of heavy metals such as $\mathrm{Zn}\left(2.43-2.98 \mathrm{mg} \mathrm{Kg}^{-1}\right)$, Cu $\left(2.39-2.73 \mathrm{mg} \mathrm{Kg}^{-1}\right)$, Ni $\left(0.55-0.91 \mathrm{mg} \mathrm{Kg}^{-1}\right)$, Cr $\left(1.01-1.21 \mathrm{mg} \mathrm{Kg}^{-1}\right), \mathrm{Cd}^{-0.13-}$ $0.17 \mathrm{mg} \mathrm{Kg}^{-1}$ ), and Fe (5.54-6.18) were observed at $100 \%$ concentration of SME than that of DAP treatment in both the cultivated seasons. However, the concentration of all the metals $\mathrm{Zn}, \mathrm{Cu}, \mathrm{Ni}, \mathrm{Cd}, \mathrm{Cr}$ and $\mathrm{Fe}$ in soil and plant were lower than toxicity threshold i.e. within the permissible limit. Enrichment factor (Ef) for soil/ $V$. unguiculata was recorded maximum with $\mathrm{Ni}$ (37.66-42.33) / (24-30.33) and minimum with Fe (3.24-3.44) / (2.28-2.52) after 90 days of SME irrigation than DAP in both the cropping seasons of Kharif and Zaid. The minimum accumulation of Fe in both soil and crop showed that metals with completely filled d orbitals (d8, Fe) were least incorporated into the V. unguiculata crop.
\end{abstract}

Keywords: Enrichment factor, Heavy metals, Sugar mill effluent, Soil characteristics, Vigna unguiculata

\section{INTRODUCTION}

Water provides the Earth with the capability of supporting life. But in today's scenario the water scarcity and water pollution pose a critical challenge both for agriculture and environment in many developing countries. The discharge of effluents, treated or untreated, into the environment, particularly in the aquatic bodies such as lakes, rivers and the coastal marine environments can cause severe degradation of these aquatic ecosystems. The growing demand of water for irrigation has resulted in a marked increase in the use of treated or untreated wastewater worldwide. Hence treated or diluted wastewater may be considered as an innovative water resource, which can be added to the general water balance of an area (Hati et al., 2007; Kumar and Chopra, 2010).

Agriculture is a vital for the Indian economy, as India has traditionally been an agrarian economy. Contamination of crops with heavy metals may be due to irrigation with contaminated water, addition of fertilizers, industrial emissions and transportation. These crops contain essential and toxic metals over a wide range of concentration, which could be injurious to plants growth and may be a potential threat to food web (Arora et al., 2008; Srivastava and Chopra, 2014). Heavy metal concentration in agricultural soils can affect human beings directly, through soil uptake and food web by ingestion of crops and animals. The toxic heavy metals entering the ecosystem may lead to geo-accumulation, bioaccumulation and biomagnifications. Heavy metals like $\mathrm{Fe}, \mathrm{Cu}, \mathrm{Zn}, \mathrm{Ni}$ and other trace elements are important for proper functioning of biological systems and their deficiency or excess could lead to a number of disorders (Singh et al., 2012).

Sugar mills are one of the most important agro-based industries, which produce sugar as an essential item of mass consumption and the cheapest source of energy. Presently, India has nearly 650 sugar mills. The overall production of sugar was 16.3 million ton and exports 0.23 million ton sugar. Sugar mills account in the industries generate huge volumes of waste without any or partially treatment during the crushing season and contain a high amount of pollution load particularly in terms of suspended solids, organic matter, press mud, bagasse, air pollutants and heavy metals (Kumar and Chopra, 2010; Kumar and Chopra, 2013).

Cowpea [Vigna unguiculata (L) Walp.] is a leguminous and dicotyledonous crop in the family Fabaceae formerly (Leguminosae) belongs to sub family ISSN : 0974-9411 (Print), 2231-5209 (Online) All Rights Reserved @ Applied and Natural Science Foundation www.ansfoundation.org 
Faboideae, genus Vigna savi and species V. unguiculata. Cowpea is adapted to high temperatures (20-35 $5^{\circ}$ ), wide range of soil texture and slightly acid to alkaline soils pH (5.5-8.3) (Valenzuela and Smith, 2002). Cowpea leaves and seeds are applied as a poultice to treat swellings and infections. The root is used as an antidote for snakebites and to treat epilepsy, chest pain, constipation and dysmenorrheal. Emetics made from the plant are used to relieve fever. The cooking liquor of the seeds with spices is considered to be a potential remedy for the common cold (Zia-ul-haq et al., 2010). On the basis of above scenario, the present study was conducted with an aim to compare the heavy metals accumulation in soil/ $V$. unguiculata irrigated with various concentrations of SME and DAP and also to assess for the better yield of the crop in two cropping seasons.

\section{MATERIALS AND METHODS}

Experimental design: A field study experiment was conducted in the Experimental garden of the Department of Zoology and Environmental Sciences, Faculty of Life Sciences, Gurukula Kangri University Haridwar $\left(29^{\circ} 55^{\prime} 10.81^{\prime \prime} \mathrm{N}\right.$ and $\left.78^{\circ} 07^{\prime} 08.12^{\prime \prime E}\right)$ during the period (2009-2010) for studying the metal accumulation in soil and V.unguiculata plant irrigated with different concentrations of SME after dilution and DAP ; and their impact on yield of the crop in two cropping seasons i.e. rainy (Kharif) and summer (Zaid) seasons. Poly bags (dia-30cm) were used for growing the V.unguiculata plant. The pots were arranged in a completely randomized design with six replicates. Forty two poly bags were filled with soil used for the cultivation of $V$. unguiculata. Proper distance was maintained between each replicate $(30 \mathrm{~cm})$, between all treatments $(60 \mathrm{~cm})$ and plant to plant $(5 \mathrm{~cm})$ for the maximum performance of the crop. Each poly bag was made porous for aeration and was labeled for the various treatments viz. 10, 25, 50, 75 and 100\% SME concentrations and DAP treatment. The Borewell water (BWW) was taken as control.

Soil preparation, filling of poly bags, sampling and analysis: The soil used for cultivation was collected at a depth of $0-15 \mathrm{~cm}$. Each poly bag $(30 \times 30 \mathrm{~cm})$ was filled with $5 \mathrm{Kg}$ of soil in each of the forty two of poly bags (the soil in each poly bag was $25 \mathrm{~cm}$ deep), earlier air-dried and sieved to remove debris and mixed with equal quantity of farmyard manure. The DAP was applied at a rate $0.7 \mathrm{~g}$ of DAP @ $100 \mathrm{Kg} / \mathrm{ha}$ per bag to all the six replicates for DAP treatment followed by (ILRI, 2010). The soil filled was irrigated twice in a week and as per the requirement of crop with $500 \mathrm{~mL}$ of SME in five concentrations 10\%, 25\%, 50\%, $75 \%$ and $100 \%$ of SME, DAP and BWW (control) separately.

Heavy metals analysis: For heavy metal analysis, 5$10 \mathrm{~mL}$ sample of effluent and 0.5-1.0 g sample of air dried soil/plant were taken in digestion tubes separately. After this $3 \mathrm{~mL}$ conc. $\mathrm{HNO}_{3}$ was added to each sample and was digested on electrically heated block for $1 \mathrm{~h}$ at $145^{\circ} \mathrm{C}$. Four $\mathrm{mL}$ of $\mathrm{HClO}_{4}$ was added and heated to $240^{\circ} \mathrm{C}$ for an additional hour. The sample was cooled and filtered through Whatman \# 42 filter paper. Its volume was made up to $50 \mathrm{~mL}$ and then used for analysis following standard methods cited in Chaturvedi and Sankar (2006).

Determination of Enrichment factor (Ef): Ef was determined to assess the accumulation of different heavy metals in soil sediment and $V$. unguiculata plants irrigated with SME/DAP treatment. The Ef was calculated to derive the degree of heavy metal accumulation in soil and plants growing in the treated soil with $100 \%$ SME irrigation with respect to soil and plants growing on control soil as stated earlier (Srivastava and Chopra, 2014).

Statistical analysis: One way analysis of variance (ANOVA) was used for data analysis to measure the variations between the soil parameters before and after irrigation of crop with different SME concentrations and DAP treatment. MS Excel, 2003 was used to measure the standard deviation (SD) and coefficient of correlation (r value).

\section{RESULTS AND DISCUSSION}

Heavy metals contents in the soil: Across the present study, a wide range of heavy metal concentrations of soil was observed with SME and DAP treatment irrigated soil. The results indicated that $\mathrm{Zn}, \mathrm{Cu}, \mathrm{Ni}, \mathrm{Cd}$, $\mathrm{Cr}$ and Fe contents at $100 \%$ concentration of SME irrigated soil were below the permissible limit of (Temmerman et al. 1984; Kabata-Pendias and Pendias 1992; Indian Standards of Awashthi 2000). However, there was considerable build up of $\mathrm{Zn} \mathrm{(3.30-3.44} \mathrm{mg}$ $\left.\mathrm{Kg}^{-1},+323.07-341.02 \%\right), \mathrm{Cu}$ (3.44-3.57 $\mathrm{mg} \mathrm{Kg}{ }^{-1}$, $+371.23-389.04 \%)$, Ni (1.13-1.27 $\mathrm{mg} \mathrm{Kg}^{-1},+3666.66-$ $4133.33 \%)$, Cr (1.39-1.42 mg Kg ${ }^{-1},+1444.4-$ $1477.77 \%), \mathrm{Cd}\left(0.25-0.33 \mathrm{mg} \mathrm{Kg}^{-1},+525.00-725.00 \%\right)$ and $\mathrm{Fe}^{2+}\left(8.88-9.45 \mathrm{mg} \mathrm{Kg}^{-1},+224.08-244.89 \%\right)$ with $100 \%$ SME concentration, while in case of DAP treatment $\mathrm{Zn}$ (0.81-0.92 $\left.\mathrm{mg} \mathrm{Kg}^{-1},+3.84-6.41 .00 \%\right)$, $\mathrm{Cu}$ (0.75-0.78 mg Kg-1, +2.73-6.84\%), Ni (0.04-0.05 $\left.\mathrm{mg} \mathrm{Kg}{ }^{-1},+33.33-66.66 \%\right)$, $\mathrm{Cr}$ (0.11-0.14 mg Kg-1, $+22.22-33.33 \%)$, Cd (0.05-0.06 mg Kg ${ }^{-1},+25.00-$ $50.00 \%)$ and $\mathrm{Fe}^{2+}\left(2.76-2.78 \mathrm{mg} \mathrm{Kg}^{-1},+0.72-1.45 \%\right)$ were recorded lower in comparison to SME irrigated soil but slightly higher than BWW irrigated soil after 90 days in both the cropping seasons of kharif and zaid (Table 1).

ANOVA analysis for soil $\mathrm{Zn}, \mathrm{Cu}, \mathrm{Ni}, \mathrm{Cr}, \mathrm{Cd}$ and $\mathrm{Fe}$ revealed that above metals were significantly $(\mathrm{P}<0.001)$ affected with SME concentrations $(10 \%$ to $100 \%$ ) in both rainy (Kharif) and summer (Zaid) seasons as compared with DAP treatment and BWW, while $\mathrm{Ni}$ was found to be significantly $(\mathrm{P}<0.001)$ affected with $25 \%$ to $100 \%$ concentrations of SME than with DAP treatment in rainy (Kharif) seasons 


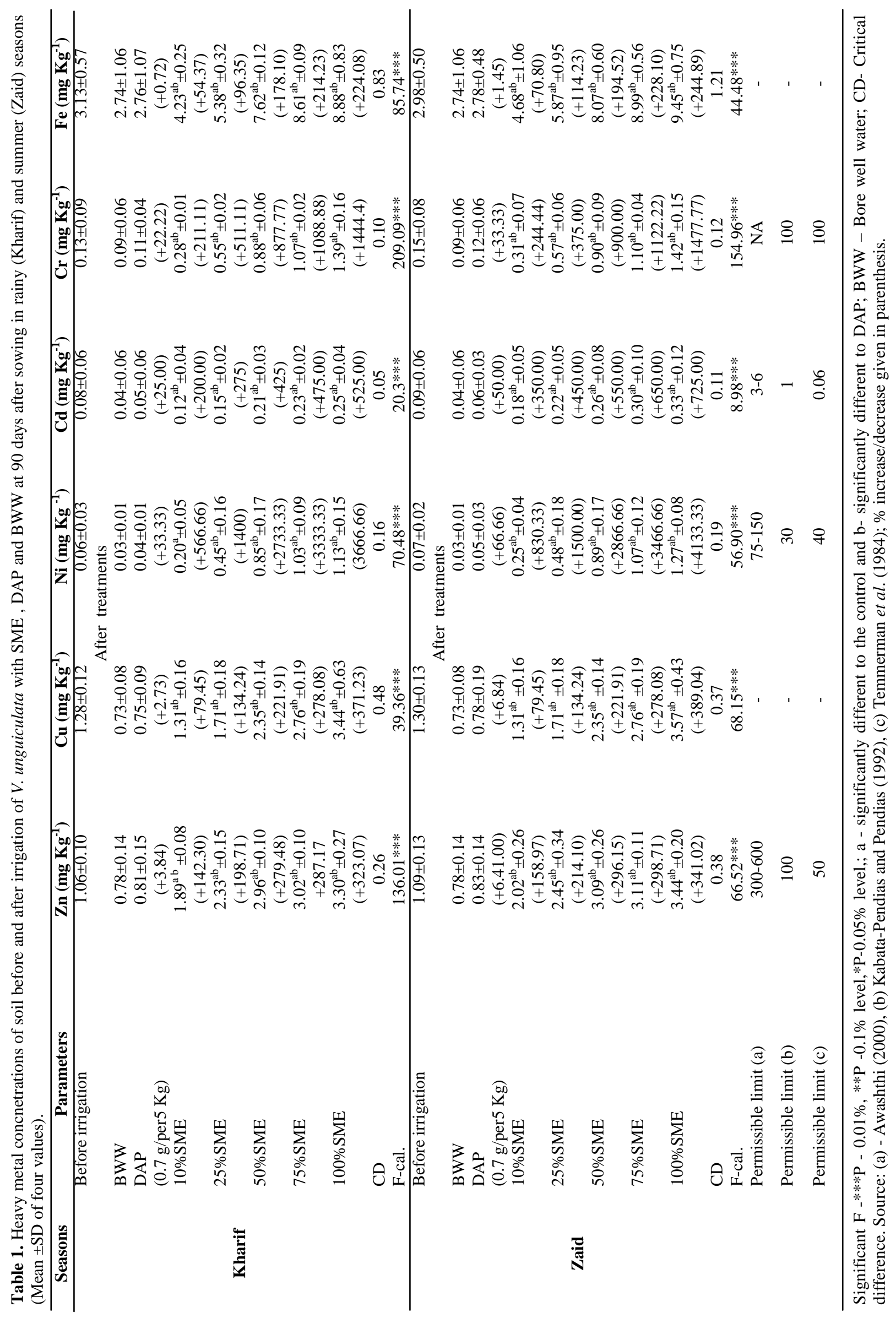


Table 3. Coefficient of correlation (r) between SME and soil and in between SME and V.unguiculata in rainy (Kharif) and summer (Zaid) seasons.

\begin{tabular}{|c|c|c|}
\hline SME vs. Soil metals & Seasons & r-value \\
\hline \multirow{2}{*}{$\mathrm{Zn}$} & Rainy (Kharif) & 0.88 \\
\hline & Summer (Zaid) & 0.89 \\
\hline \multirow{2}{*}{$\mathrm{Cu}$} & Rainy (Kharif) & 0.99 \\
\hline & Summer (Zaid) & 0.99 \\
\hline \multirow{2}{*}{$\mathrm{Cd}$} & Rainy (Kharif) & 0.93 \\
\hline & Summer (Zaid) & 0.96 \\
\hline \multirow{2}{*}{$\mathrm{Cr}$} & Rainy (Kharif) & 0.99 \\
\hline & Summer (Zaid) & 0.99 \\
\hline \multirow{2}{*}{$\mathrm{Ni}$} & Rainy (Kharif) & 0.97 \\
\hline & Summer (Zaid) & 0.97 \\
\hline \multirow{2}{*}{$\mathrm{Fe}$} & Rainy (Kharif) & 0.95 \\
\hline & Summer (Zaid) & 0.96 \\
\hline \multicolumn{3}{|c|}{ SME vs. $V$. unguiculata } \\
\hline \multirow{2}{*}{$\mathrm{Zn}$} & Rainy (Kharif) & 0.86 \\
\hline & Summer (Zaid) & 0.91 \\
\hline \multirow{2}{*}{$\mathrm{Cu}$} & Rainy (Kharif) & 0.98 \\
\hline & Summer (Zaid) & 0.98 \\
\hline \multirow{2}{*}{$\mathrm{Cd}$} & Rainy (Kharif) & 0.98 \\
\hline & Summer (Zaid) & 0.99 \\
\hline \multirow{2}{*}{$\mathrm{Cr}$} & Rainy (Kharif) & 0.98 \\
\hline & Summer (Zaid) & 0.99 \\
\hline \multirow{2}{*}{$\mathrm{Ni}$} & Rainy (Kharif) & 0.99 \\
\hline & Summer (Zaid) & 0.99 \\
\hline \multirow{2}{*}{$\mathrm{Fe}$} & Rainy (Kharif) & 0.95 \\
\hline & Summer (Zaid) & 0.97 \\
\hline
\end{tabular}

(Table 1). The coefficient of correlation for soil $\mathrm{Zn}$, $\mathrm{Cu}, \mathrm{Ni}, \mathrm{Cr}, \mathrm{Cd}$ and $\mathrm{Fe}$ revealed that these metals were positively correlated with increasing concentrations of the SME in both rainy (Kharif) and summer (Zaid) seasons as compared with DAP treatment and BWW (Table 3).

Excessive accumulation of heavy metals in agricultural soils through effluent irrigation may not only result in soil contamination, but also affect food quality and safety (Muchuweti et al., 2006; Srivastava and Chopra, 2014). Earlier studies by Pandey (2006) and Lahham et al. (2007) on heavy metals revealed that metals concentrations increase in the soil on irrigation with electroplating and sewage wastewater respectively. Qishlaqi et al. (2008) recorded higher values for $\mathrm{Zn}$ (12.4-198.9 $\left.\mathrm{mgKg}^{-1}\right)$, Ni (14.6-313.6 $\left.\mathrm{mgKg}^{-1}\right), \mathrm{Cd}$ (0.09-3.30 $\left.\mathrm{mgKg}^{-1}\right)$ and $\mathrm{Cr}$ (2.1-35.1 $\left.\mathrm{mgKg}^{-1}\right)$ in wastewater irrigated soils. They showed that concentrations of heavy metals in wastewater-irrigated soils were higher than those in control site. Greater concentrations of heavy metals in soil under wastewater irrigation were probably due to greater amount of wastewater used for irrigation of soil near Khoshk river channel in suburban area of Shiraz City, SW Iran. On an average, wastewater irrigation resulted in $4.5 \%$ and $4 \%$ increase in the $\mathrm{Ni}$ and $\mathrm{Cd}$ concentrations, respectively, in the soils of Shiraz suburban area, SW Iran. Samuel and Muthukkaruppan (2011) reported that polluted soil of industrial area in Cuddalore

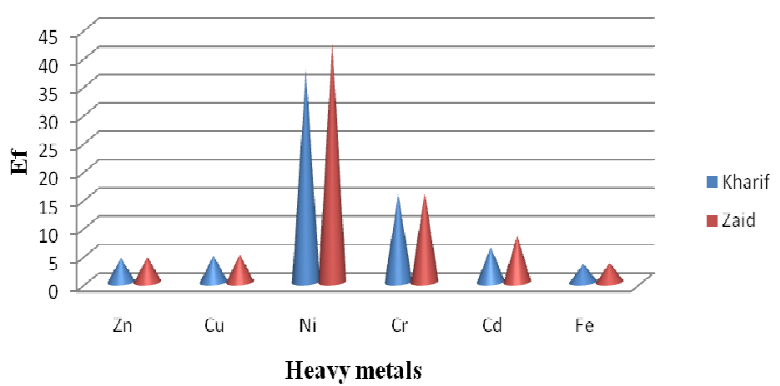

Fig. 1. Ef for heavy metals of soil irrigated with SME in rainy (Kharif) and summer (Zaid) seasons.

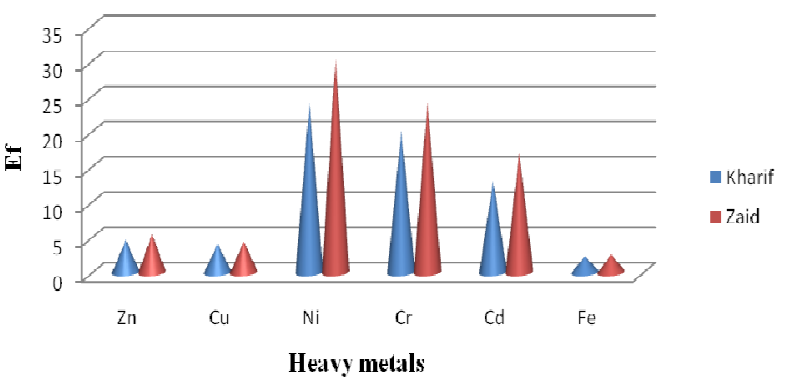

Fig. 2. Ef for heavy metals of $V$. unguiculata irrigated with SME in rainy (Kharif) and summer (Zaid) seasons.

district, Tamil Nadu, India irrigated with SME had higher amount of $\mathrm{Cu}\left(0.75 \mathrm{mgKg}^{-1}\right), \mathrm{Zn}\left(7.28 \mathrm{mgKg}^{-1}\right)$, and $\mathrm{Fe}\left(21.28 \mathrm{mgKg}^{-1}\right)$. The polluted soil was found with excess/ less amount of micro and macronutrients which will reduce the plant growth. Kumar and Chopra (2013) reported a built of heavy metals i.e. Zn (9.12-11.78 $\left.\mathrm{mgKg}^{-1}\right)$, Cd (1.87-1.98 $\left.\mathrm{mgKg}^{-1}\right), \mathrm{Cu}$ (13.96-14.39 $\left.\mathrm{mgKg}^{-1}\right)$, and $\mathrm{Cr}\left(1.72-1.97 \mathrm{mgKg}^{-1}\right)$ in the soil of experimental garden irrigated with $100 \%$ SME concentrations than control for Sorghum bicolor in both the cropping seasons.

Ef for heavy metals in SME irrigated soil: In the present study Ef for various heavy metals in soil recorded for $\mathrm{Zn}$ (4.23/4.41), $\mathrm{Cu}$ (4.71/4.89), Ni (37.66/42.33), $\mathrm{Cr}$ (15.44/15.77), $\mathrm{Cd}(6.25 / 8.25)$ and $\mathrm{Fe}$ (3.24/3.44) in both the cropping seasons after 90 days of SME irrigation in soil. The $\mathrm{Zn}, \mathrm{Cu}, \mathrm{Cd}$ and $\mathrm{Fe}$ were found in considerable enrichment category, while $\mathrm{Ni}$ and $\mathrm{Cr}$ were found to be in significant enrichment category on irrigation with SME in both the cropping seasons (Fig. 1). Among various heavy metals maximum Ef was recorded with $\mathrm{Ni}(37.66 / 42.33)$ and minimum with $\mathrm{Fe}(3.24 / 3.44)$ and was found in the order $\mathrm{Ni}>\mathrm{Cr}$ $>\mathrm{Cd}>\mathrm{Cu}>\mathrm{Zn}>\mathrm{Fe}$ in both the cropping seasons after 90 days of SME irrigation in soil than for DAP treatment applied soil. This may be likely due to maximum content of $\mathrm{Ni}$ and minimum of $\mathrm{Fe}$ enrichment in soil irrigated with $100 \%$ SME concentration than that of DAP treatment applied soil. Similarly, Moore et al. (2011) have reported that $\mathrm{Ni}$ was significantly enriched, while $\mathrm{Cu}, \mathrm{Cd}$ and $\mathrm{Cr}$ were classified as moderately enriched along Khoshk river soil, whose main sources of heavy metals were municipal, domestic, and illegal discharges of industrial effluents. 
Chopra and Pathak (2013) also reported maximum Ef for $\mathrm{Ni}$ and minimum for $\mathrm{Fe}$ in the experimental garden soil irrigated with SME for cultivation of Spinacea oleracea.

Heavy metals accumulation in $V$. unguiculata irrigated with SME: The maximum range of heavy metals in $V$. unguiculata viz. $\mathrm{Zn}\left(2.43-2.67 \mathrm{mg} \mathrm{Kg}^{-1}\right)$, $\mathrm{Cu}$ (2.32-2.48 $\left.\mathrm{mg} \mathrm{Kg}^{-1}\right)$, Ni (0.55-0.75 $\left.\mathrm{mg} \mathrm{Kg}^{-1}\right), \mathrm{Cr}$ (0.93-1.10 $\left.\mathrm{mg} \mathrm{Kg}^{-1}\right), \mathrm{Cd}\left(0.13-0.25 \mathrm{mg} \mathrm{Kg}^{-1}\right)$, and $\mathrm{Fe}$ (5.54-6.61) were observed with $100 \%$ concentration of SME, while in case of DAP treatment applied soil $\mathrm{Zn}$ (0.26-0.53 $\left.\mathrm{mg} \mathrm{Kg}^{-1}\right), \mathrm{Cu}\left(0.31-0.59 \mathrm{mg} \mathrm{Kg}^{-1}\right)$, Ni (0.03$\left.0.04 \mathrm{mg} \mathrm{Kg}^{-1}\right), \mathrm{Cr}\left(0.04-0.07 \mathrm{mg} \mathrm{Kg}^{-1}\right), \mathrm{Cd}(0.03-0.05$ $\left.\mathrm{mg} \mathrm{Kg}{ }^{-1}\right)$, and $\mathrm{Fe}$ (1.51-1.58 $\mathrm{mg} \mathrm{Kg}^{-1}$ ) were recorded lower in comparison to SME irrigated soil but slightly higher than BWW irrigated soil after 90 days in both the cropping seasons. Among DAP treatment and SME concentrations, maximum accumulation of heavy metals in $V$. unguiculata was recorded at $100 \%$ concentration of SME in both the cropping seasons (Table 2). The concentrations of $\mathrm{Zn}, \mathrm{Cu}, \mathrm{Ni}, \mathrm{Cr}$ and $\mathrm{Fe}$ in the V.unguiculata grown with $100 \%$ concentration of SME irrigated soil were below the permissible limit when compared to the Indian Standard (Awashthi, 2000; SEPA, 2005; FAO/WHO standard Codex Alimentarius Commission 2011), except Cd (0.25-0.30 $\mathrm{mgKg}^{-1}$ ) which was above the permissible limit of (SEPA, 2005; FAO/WHO standard Codex Alimentarius Commission 2011) in both the cropping seasons (Table 4). This may be likely due to increased irrigation frequency that could lead to increased metals accumulation in $V$. unguiculata. It has also been observed by Itanna (2002) and Muchuweti et al. (2006) that $V$. unguiculata had low accumulation of heavy metals in contrast with other leafy vegetables. This is due to the fact that leafy vegetables have high translocation rate and high transpiration rate as compared to other vegetables and also the transfer of metals from root to stem and further to the fruit (vegetable) is lower which results in low accumulation of heavy metals than in leafy vegetables.

Pandey (2006) reported the higher concentrations of $\mathrm{Zn}\left(146.8 \pm 11.8 / 140.2 \pm 10.5 \mu \mathrm{g} \mathrm{g}^{-1}\right), \mathrm{Cu}(81.2 \pm 26.5 /$ $\left.41.0 \pm 7.89 \mu \mathrm{g} \mathrm{g}^{-1}\right), \mathrm{Cr}\left(302.0 \pm 28.9 / 198.0 \pm 36.4 \mu \mathrm{g} \mathrm{g}^{-1}\right)$, $\mathrm{Cd}\left(0.742 \pm 0.019 / 0.86 \pm 0.09 \mu \mathrm{g} \mathrm{g}^{-1}\right)$ and $\mathrm{Ni}(155.1$ $\pm 17.4 / 84.2 \pm 18.6 \mu \mathrm{g} \mathrm{g}^{-1}$ ) in $S$. oleracea/R. sativus irrigated with $100 \%$ concentration of industrial effluent in pots experiments. Farooq et al. (2008) also observed accumulation of various heavy metals such as $\mathrm{Cd}$ (0.011-0.073 mg Kg $\left.{ }^{-1}\right), \mathrm{Cu}\left(0.161-0.923 \mathrm{mg} \mathrm{Kg}^{-1}\right), \mathrm{Zn}$ (0.361-1.893 $\left.\mathrm{mg} \mathrm{Kg}^{-1}\right)$ and $\mathrm{Cr}\left(1.121-2.254 \mathrm{mg} \mathrm{Kg}^{-1}\right)$ in Cabbage, Spinach, Lettuce and Cauliflower respectively which were less than the permissible limit as recommended by maximum acceptable levels proposed by the Joint FAO/WHO Expert Committee on Food Additives. Kumar and Chopra, (2013) recorded maximum accumulation of various heavy metals such as $\mathrm{Zn}, \mathrm{Cd}, \mathrm{Cu}$ and $\mathrm{Cr}$ contents in Sorghum bicolor at $100 \%$ concentration of SME in both the rainy (Kharif) and summer (Zaid) seasons and inhibited the growth of the crop.

In present study, ANOVA analysis on the data showed that accumulation of the heavy metals in the $V$. unguiculata were significantly $(\mathrm{P}<0.05)$ affected with different SME concentrations. The concentration of heavy metals such as $(\mathrm{Zn}$ and $\mathrm{Cu}$ from $10 \%$ to $100 \%$ SME concentrations), (Cr, $\mathrm{Cd}$, and $\mathrm{Fe}$ from $25 \%$ to $100 \%$ SME concentrations) and (Ni from $50 \%$ to $100 \%$ SME concentrations) were significantly $(\mathrm{P}<0.001)$ different than that of DAP treatment in both the rainy (Kharif and summer (Zaid) seasons (Table 2). The $\mathrm{Zn}, \mathrm{Cu}, \mathrm{Ni}, \mathrm{Cd}, \mathrm{Cr}$ and $\mathrm{Fe}$ in the crop showed their positive correlation with different SME concentrations ranging from $0 \%$ to $100 \%$ in both the cultivated seasons (Table 3).

Ef for heavy metals in $\boldsymbol{V}$. unguiculata irrigated with SME: In the present study, Ef values for various heavy metals in $V$. unguiculata plants recorded for $\mathrm{Zn}, \mathrm{Cu}$, $\mathrm{Ni}, \mathrm{Cr}, \mathrm{Cd}$ and $\mathrm{Fe}$ in both the cropping seasons after 90 days of SME irrigation and DAP treatment are indicated in Fig. 2. Among various heavy metals, maximum Ef was recorded for $\mathrm{Ni}$ (24/30.33) and minimum for $\mathrm{Fe}(2.28 / 2.52)$ in $V$. unguiculata in both the cropping seasons, thereby indicating the presence of $\mathrm{Ni}$ in maximum enrichment and that of $\mathrm{Fe}$ in maximum enrichment category. This is in accordance with Moshood and Agakwu (2007) who reported that $\mathrm{Ni}$ was found to be in significant enrichment category for A.esculentus, which exhibited 2 to 5 fold accumulation of analyzed trace metals as compared with Amarunthus species that exhibited 2 to 10 fold accumulation of trace metals viz. $\mathrm{Ni}, \mathrm{Cr}, \mathrm{Cu}, \mathrm{Cd}$ and $\mathrm{Zn}$ with treated wastewater, thereby showing that uptake and phytotoxic accumulation of potentially toxic trace metals is plant dependent. Farooq et al. (2008) observed higher concentration of various heavy metals such as $\mathrm{Cd}, \mathrm{Cu}, \mathrm{Zn}$, and $\mathrm{Cr}$ in cabbage, spinach, lettuce and cauliflower on irrigation with industrial effluent. Srivastava and Chopra (2014) reported that among $\mathrm{Ni}, \mathrm{Cu}, \mathrm{Cr}, \mathrm{Cd}$ and $\mathrm{Zn}$, maximum Ef value was recorded for $\mathrm{Ni}$ (12.5) and the minimum for $\mathrm{Zn}$ (5.54), thereby, showing higher accumulation of $\mathrm{Ni}$ and lower accumulation of $\mathrm{Zn}$ in A. esculentus on irrigation with different concentrations of distillery effluent.

\section{Conclusion}

The irrigation with SME showed significant increase of $\mathrm{Zn}, \mathrm{Fe}, \mathrm{Cu}, \mathrm{Cd}, \mathrm{Cr}$ and $\mathrm{Ni}$ in soil and V. unguiculata crop. However, the concentration of the heavy metals in soil and crop on irrigation with 100\% SME concentrations, were lower than the toxicity threshold i.e. within the permissible limit except for $\mathrm{Cd}$ in $V$. unguiculata was slightly higher than the permissible limits in both cropping seasons. The values of Ef indicated that there was maximum accumulation of $\mathrm{Ni}$ and minimum of $\mathrm{Fe}$ for $V$. unguiculata on irrigation 
with $100 \%$ concentration of SME in both the cropping seasons. The minimum accumulation of $\mathrm{Fe}$ in both soil and crop showed that metals with completely filled $\mathrm{d}$ orbitals $(\mathrm{d} 8, \mathrm{Fe})$ were least incorporated into the $V$. unguiculata crop, probably due to lower reactivity and more stability imparted by the completely filled $\mathrm{d}$ orbital's. It was suggested that the agro-potentiality of the industrial effluents should be monitored for the accumulation of heavy metals in the soil and crops to check the environmental hazards, if any.

\section{REFERENCES}

Arora, M., Kiran, B., Rani, S., Rani, A., Kaur, B. and Mittal, N. (2008). Heavy metal accumulation in vegetables irrigated with water from different sources. Food Chemistry, 111: 811-815.

Awashthi, S.K. (2000). Prevention of Food Adulteration Act no. 37 of 1954. Central and State Rules as amended for 1999,third ed. Ashoka Law House, New Delhi.

Chaturvedi, R.K. and Sankar, K. (2006). Laboratory manual for the physico-chemical analysis of soil, water and plant. Wildlife Institute of India, Dehradun, pp. 97.

Chopra, A.K. and Pathak, C. (2013). Enrichment and translocation of heavy metals in soil and Spinacea oleracea grown in Sugar mill effluent irrigated soil. Sugar Tech., 15:77-83.

FAO/WHO. (2011). Joint FAO/WHO food standards programme codex committee on contaminants in foods. fifth session, Food and Agricultural Organization/World Health Organization, pp 64-89.

Farooq, M., Farooq, A. and Rashid, U. (2008). Appraisal of heavy metal contents in different vegetables grown in the vicinity of an industrial area. Pakistan Journal of Botany, 40: 2099-2106.

Hati, K.K., Swarup, A. and Dwivedi, A.K. (2007). Changes in soil physical properties and organic carbon status at the topsoil horizon of a Vertisol of central India after 28 years of continuous cropping, fertilization and manuring. Agric. Ecosyst. Environ., 119: 127-134.

Itanna, F. (2002). Metals in leafy vegetables grown in Addis Ababa and toxicological implications. Ethiopian Journal of Health Development, 6:295-302.

Kabata-Pendias, A. and Pendias, H. (1992). Trace elements in soil and plants, 2nd edn. Boca Raton: CRC, USA, pp 365.

Kumar, V. and Chopra, A. K. (2010). Influence of Sugar mill effluent on physico-chemical characteristics of soil at Haridwar (Uttarakhand), India. Journal of Applied and Natural Science, 2(2):269-279.

Kumar, V. and Chopra , A.K. (2013) Response of sweet sorghum after fertigation with sugar mill effluent in two seasons. Sugar Tech., 15(3):285-299.

Lahham, O., El Assi, N.M. and Fayyad, M. (2007). Translocation of heavy metals to tomato (Solanum lycopersi$\operatorname{com}$ L.) fruit irrigated with treated wastewater. Scientia Horticulturae, 113:250-254.

Moore, F., Attar, A. and Rastmanesh, F. (2011). Anthropogenic sources of heavy metals in deposited sediments from runoff and industrial effluents, Shiraz, SW Iran. International Proceedings of Chemical, Biological \& Environmental Engineering, 6:215-219.

Moshood, N.T. and Agakwu, A.A. (2007). An assessment of soil - plant transfer of trace metals and contamination of shallow ground water under amended irrigated fields. African crop science conference proceedings, 8:16931697.

Muchuweti, M., Birkett, J.W., Chinyanga, E., Zvauya, R., Scrimshaw, M.D. and Lister, J.N. (2006). Heavy metal content of vegetables irrigated with mixtures of wastewater and sewage sludge in Zimbabwe: implication for human health. Agri. Ecosys. Environ., 112:41-48.

Pandey, S.N. (2006). Accumulation of heavy metals $(\mathrm{Cd}, \mathrm{Cr}$, $\mathrm{Cu}, \mathrm{Ni}$ and $\mathrm{Zn}$ ) in Raphanus sativus L. and Spinacia oleracea L. plants irrigated with industrial effluent. Journal of Environmental Biology, 27(2):381-384.

Qishlaqi, A., Moore, F. and Forghani, G. (2008). Impact of untreated wastewater irrigation on soils and crops in Shiraz suburban area, SW Iran. Environ. Monit. Assess. 141(1-3):257-273.

Samuel, S. and Muthukkaruppan, S.M. (2011). Amelioration of Sugar mill effluent polluted soil using microbial isolates and its response on Paddy. Current Botany, 2 (8): $14-18$.

SEPA (2005). The limits of pollutants in food. State Environmental Protection Administration, China, GB 27622005.

Temmerman, L.O., Hoeing, M. and Scokart, P.O. (1984). Determination of 'normal' levels and upper limit values of trace elements in soils. Zournal Pflanzenernahr Bodenkd, 147: 687-694.

Valenzuela, H. and Smith, J. (2002). Cowpea, college of Tropical Agriculture and Human Resources. University of Hawaii at Monoa, Honolulu, Hawaii. pp 1-4.

Zia-ul-haq, M., Ahmad, S.E., Chiavaro, M. and Ahmed, S. (2010). Studies of oil from cowpea (Vigna unguiculata (1.) Walp.) cultivars commonly grown in Pakistan. Pak. J. Bot., 42(2):1333-1341.

Singh, R., Gautam, N., Mishra, A. and Gupta, R. (2012). Heavy metals and living systems: An overview. Indian $J$ Pharmacology, 43(3): 246-253.

Srivastava, S. and Chopra, A.K. (2014). Irrigational impact of distillery effluent on Abelmoschus esculentus L. Okra with special reference to heavy metals. Environ. Monit. Assess. DOI 10.1007/s10661-014-3688-7. 